\title{
INFLUENCE OF SFRC LAYER ON DEFLECTIONS AND CRACKS OF COMPOSITE RC SLAB
}

\author{
B. SADOWSKA-BURACZEWSKA ${ }^{1}$
}

\begin{abstract}
This paper presents an experimental analysis of flexural capacity and deformability of structural concrete slabs prepared as composite members consisting of two concrete layers made of reinforced ordinary concrete $(\mathrm{N})$ and fiber reinforced concrete (SFRC). The reinforced concrete composite slabs used in the tests were prepared in the dimensions of $600 \times 1200 \times 80 \mathrm{~mm}$. The basis was composed of two layers consisting of SFRC, one as the top layer, and one as ordinary concrete. The results of the analysis confirm a significant improvement of structural properties of the composite slab in comparison to the slabs prepared wholly of ordinary concrete.
\end{abstract}

Keywords: deflections, cracks, SFRC, composite slabs, carrying capacity, experimental study

\section{INTRODUCTION}

Fiber-reinforced concrete is a well-known material, subject to numerous scientific studies. In a plethora of articles $[1,2,3,4,5,6]$ and publications there is information on physicomechanical properties of fiber-reinforced concrete $[7,8,9,10,11,14]$. We can find few publications about FRC as a construction element (for example slabs, beams, etc.) $[12,13,15,16,17,18]$. We can also find information on standards $[20,21,22]$. Nonetheless, research is underway with to the goal of obtaining optimal fibers, identifying their best use and most appropriate quantity in concrete design, as well as methods of transport and possibilities of producing structural elements. There are very few publications on the use of fiber concrete as concrete overlay or as a repair material. The author of this publication proposes the use of fiber concrete as a reinforcing layer (or repair) in slab elements made as a composite concrete-concrete type. This publication describes short-term results

\footnotetext{
${ }^{1} \mathrm{PhD}$., Eng., Bialystok University of Technology, Faculty of Civil and Environmental Engineering, Wiejska $45 \mathrm{E}$, 15-351 Białystok, Poland, e-mail: barbara.sadowska@pb.edu.pl
} 
of using concrete with spread fibers in the model, composite slabs of the concrete-concrete type $(\mathrm{SFRC} / \mathrm{N})$ and a control, homogeneous and made of ordinary concrete $(\mathrm{N})$. Presented are standard tests of concrete properties and experimental studies on slabs, in relation to their deflections, load capacity, deformations along the height of the element, and cracks. Appropriate fiber concretes meeting the parameters assumed by the author were used to produce the elements, applying $13 \mathrm{~mm}$ long steel fibers and characterized by a compressive strength of approximately $150 \mathrm{MPa}$. The objective of the experimental studies presented in this paper, as well as that of the results analysis, is to evaluate the impact of the fiber concrete layer applied in the compressed upper zone of the element along its entire deflection length, load capacity, and cracks in concrete-concrete type composite slabs, compared to control slabs made entirely of ordinary concrete.

\section{EXPERIMENTAL ANALYSIS}

\subsection{EXPERIMENT DETAILS}

After the samples were formed into the shape of a cube $(100 \times 100 \times 100 \mathrm{~mm})$, a beam $(100 \times 100 \times 400 \mathrm{~mm})$, and a cylinder $(\varnothing 150 \times 300 \mathrm{~mm})$, and after 28 days of maturing in air-dry conditions, the following parameters of concrete, listed in Table 1, were obtained. The compressive strength test was conducted on three $100 \times 100 \times 100 \mathrm{~mm}$ cubic specimens in accordance with $[21,22]$ and we can see this test in Fig. 1.

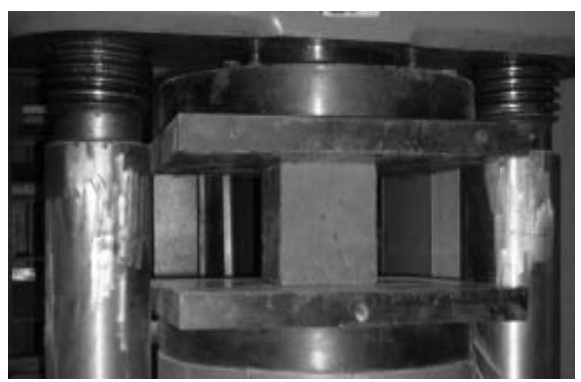

Fig. 1. The cubic sample inside the testing machine 
In the Fig. 2 the tested beam element.

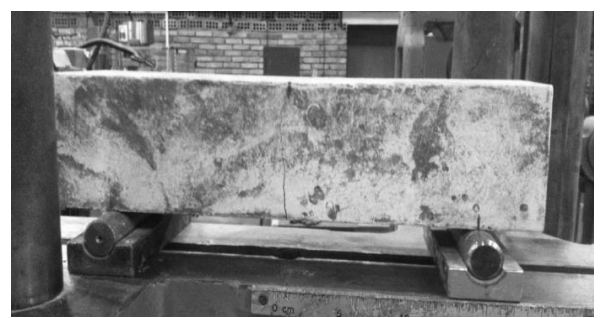

Fig. 2. Experimental test of beam element 100x100x400mm

The examinations were conducted in accordance with the applicable Eurocode rules [21, 22].

\subsection{Experiment investigations}

The reinforced concrete composite slabs were prepared with the dimensions of $600 \times 1200 \times 80 \mathrm{~mm}$. The composite slabs were cast as follows:

- Ordinary concrete as the bottom layer

- SFRC layer on the top of the beam with a thickness of $30 \mathrm{~mm}$

The FRC composition was elaborated based on CEM I 52.5 cement, quartz sand aggregate 0.2$0.8 \mathrm{~mm}$, silica fume, and superplasticising and Bekaert steel fibers of $13 \mathrm{~mm}$ length, diameter of $0.20 \mathrm{~mm}$ and $\mathrm{R}_{\mathrm{m}} \min$ tensile strenght $=2000 \mathrm{~N} / \mathrm{m}^{2}$. In ordinary concrete composition: CEM 32.5 and natural fine aggregate of 0-2 $\mathrm{mm}$ and 2-8 $\mathrm{mm}$ was used. Typical characteristics of concrete mixes and mechanical properties in the hardened state of the concrete used in the experimental slabs are given in Table 1.

Table 1. Data composition and mix characteristics of the concrete used in the tests.

\begin{tabular}{|c|c|c|c|c|c|c|c|c|c|}
\hline \multirow{3}{*}{ Concrete } & \multicolumn{2}{|c|}{$\begin{array}{c}\text { Mix characteristics } \\
\text { of concrete } \\
\text { per } 1 \mathrm{~m}^{3}\end{array}$} & \multicolumn{9}{|c|}{ Mean strength of concrete } \\
\cline { 2 - 10 } & $\mathrm{w} / \mathrm{c}$ & $\mathrm{k} / \mathrm{c}$ & $\mathrm{s} / \mathrm{c}$ & $\begin{array}{c}\mathrm{f}_{\text {cm,cube }} \\
{[\mathrm{MPa}]}\end{array}$ & $\begin{array}{c}\text { standard } \\
\text { deviation }\end{array}$ & $\begin{array}{c}\text { variability } \\
\text { index }[\%]\end{array}$ & $\begin{array}{c}\mathrm{f}_{\text {ctm }} \\
{[\mathrm{MPa}]}\end{array}$ & $\begin{array}{c}\text { standard } \\
\text { deviation }\end{array}$ & $\begin{array}{c}\text { variability } \\
\text { index }[\%]\end{array}$ \\
\hline $\mathrm{SFRC}$ & 0.22 & 0.73 & 0.1 & 151.25 & 2.081 & 1.38 & 23.63 & 2.854 & 12.08 \\
\hline $\mathrm{N}$ & 0.50 & 4.13 & ---- & 25.35 & 1.169 & 4.61 & 2.1 & 0.118 & 5.61 \\
\hline
\end{tabular}

After 28 days of curing the samples in an air-dry environment, tests were performed, including the observations and measurements of selected mechanical properties: 
- Slab deflections measured at one-half span of each slab

- Analysis of the crack pattern during loading

- Bending capacity for the basic and control slabs.

Based on preliminary model slab analyses, the tested slabs were singly reinforced with ribbed steel bars of class $\mathrm{C}$ according to [20]. The characteristics of the main and control slabs and reinforcement in respective series are given in Fig.3.
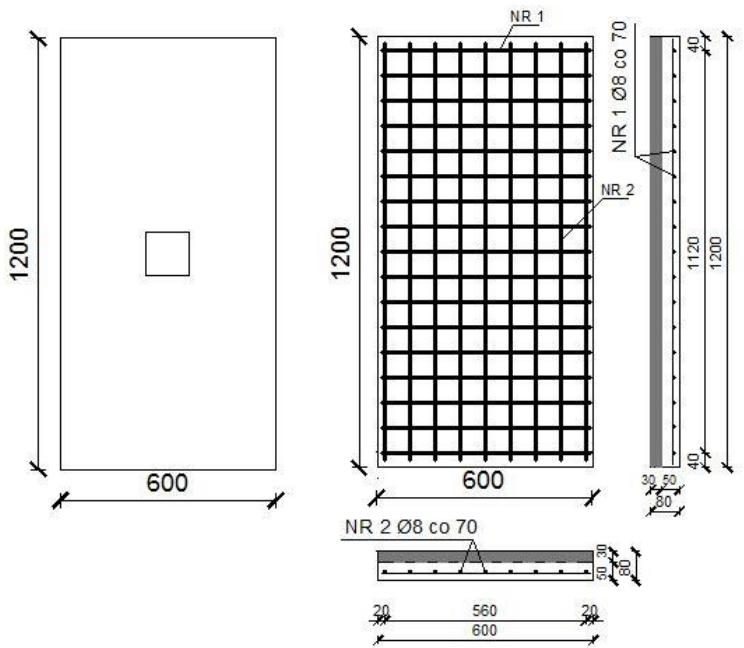

Fig. 3. The reinforcement bars in tested slabs.

The slabs were tested with a Controls hydraulic press at the Department of Construction, Materials, Technology, and Organization with a movement gain speed adjustment and registration of bend and force values. The testing station is shown in Fig.4. Before the tests were conducted, the machine had been properly calibrated and prepared. The testing images were visible on a computer screen that was connected with the press and registered the entire testing process.

Localized loads were applied to composite and control slabs. The load was applied in the centre of the element, through a centrally located steel plate with continuous load increase. The concentrated load subjected to the tested slabs was registered with an accuracy of $5 \mathrm{kN}$.

Each series consists of three slabs. The cross-sections of the specimens and the loading conditions during testing are shown in Fig.4. The view of the composite slab is presented in Fig.4. The SFRC layer at the top is marked dark grey. 

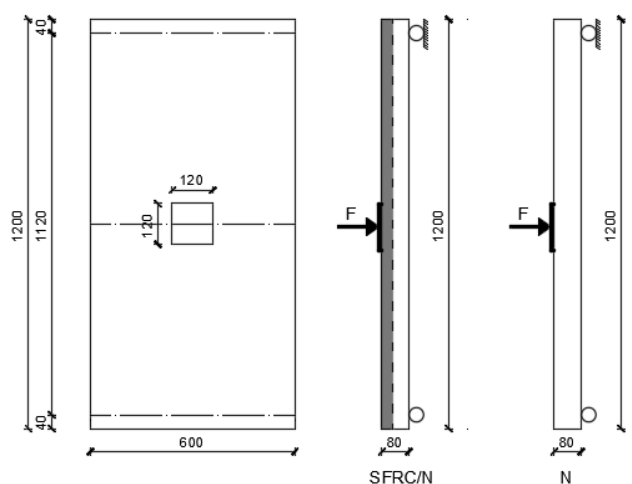

Fig.4. Loading scheme, cross-sections of the tested slabs: SFRC/N - composite slabs, N- control homogeneous slabs made of ordinary concrete.

\subsection{ANALYSIS OF SHORT-TIME EFFECTS UNDER BENDING}

The measured values of slab deflections are related to the mean values for all the samples tested in each series for the chosen force level. Selected results of the experiments, describing experimental relationships between the loading force $F$, the deflection $a$, and the carrying capacity for the composite slabs as well as for the homogeneous control slabs are presented in Fig. 5.

The quantitative effects of the use of the SFRC layer on the composite slab behavior is defined as the coefficient $k_{\alpha}$ computed by the general formula [19]:

$$
k_{\propto}=\propto_{N} / \propto_{F R C}
$$

where:

$\alpha_{N}$ - effects (deflection, crack) measured on the homogeneous control slabs made of ordinary concrete $\alpha_{F R C}-$ respective effect measured on the slabs made with the use of the SFRC layer 


\subsection{DEFLECTIONS}

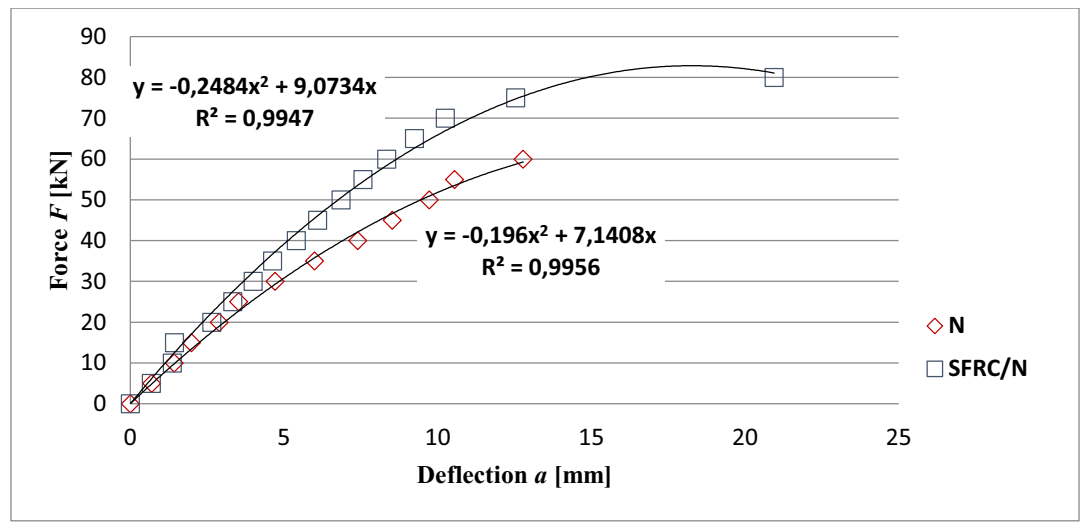

Fig. 5. Experimental relationships obtained from an experimental analysis of the loading force $F$ - deflection $a$.

The selected values of the coefficient $k_{a}$ computed for measured deflections through the above formula for a select three levels of the load are presented in Table 2.

Table 2. Quantitative effects of the use of the SFRC layer on slab deflection

\begin{tabular}{|c|c|c|c|c|c|c|c|c|}
\hline \multirow{3}{*}{ Slab type } & \multicolumn{9}{|c|}{ Deflection a [mm] } \\
\cline { 2 - 10 } & \multicolumn{2}{|c|}{$F=20[\mathrm{kN}]$} & \multicolumn{2}{c|}{$F=30[\mathrm{kN}]$} & \multicolumn{2}{c|}{$F=35[\mathrm{kN}]$} & \multicolumn{2}{c|}{$F=40[\mathrm{kN}]$} \\
\cline { 2 - 10 } & $\mathrm{a}$ & $k_{\alpha}$ & $\mathrm{a}$ & $k_{\alpha}$ & $\mathrm{a}$ & $k_{\alpha}$ & $\mathrm{a}$ & $k_{\alpha}$ \\
\hline Control N & 2.895 & 1.00 & 4.708 & 1.00 & 5.999 & 1.00 & 7.398 & 1.00 \\
\hline Composite SFRC/N & 2.656 & 1.09 & 3.996 & 1.18 & 4.634 & 1.29 & 5.399 & 1.37 \\
\hline
\end{tabular}

The results of the experiment in Table 2 indicate that the tested reinforced concrete composite slabs made with the partial use of SFRC have a relatively higher stiffness in comparison to the stiffness of the homogeneous control slabs made of ordinary concrete. This stiffness is due to stress and strain state redistribution in the zone of contact between the SFRC and the ordinary concrete.

\subsection{CRACKS}

The cracks visible in the below photos (Fig. 6 and Fig. 7) show the cracking state of both the SFRC/N and $\mathrm{N}$ slabs after destruction. During the experiment, the first cracks in all slabs of both series appeared in the middle of the element's surface. In the SFRC/N series, the first crack appeared at the force of $17 \mathrm{kN}$, yet in the $\mathrm{N}$ series it was already visible at $10 \mathrm{kN}$. Together with the load increase, perpendicular cracks appeared along the entire surface of the tested elements. Although the observed 
number of perpendicular cracks in composite slabs (see Fig. 6) was higher than in the $\mathrm{N}$ series control slabs (see Fig. 7), their width was much smaller. Over the course of testing only one crack in the $\mathrm{N}$ series slabs kept increasing its width, whereas in the composite SFRC/N series slabs (visible in Fig. 6) small radiating cracks, and, in the middle of the slab span, a crack that permeates the layer of fiberreinforced concrete without being noticeable lost motion. The test was conducted until the fibers of the area where the load was applied were destroyed. Fig. 6 and 7 show experimental cracks for the composite slab (SFRC/N) and for the slab made of ordinary concrete $-\mathrm{N}$.

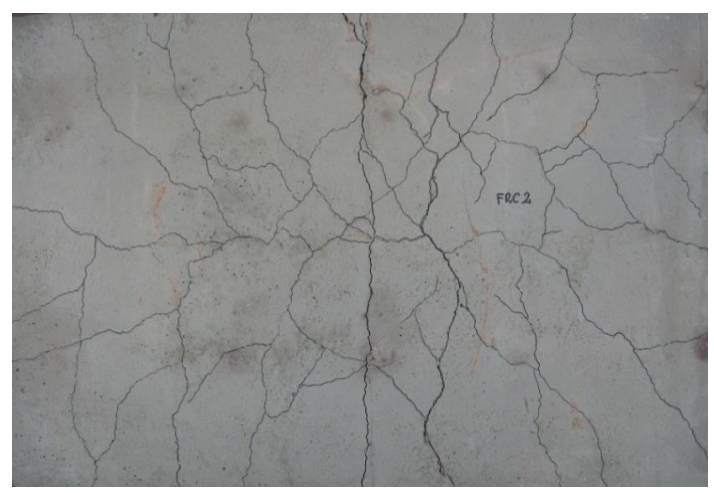

Fig. 6. Experimental cracks for the composite slab SFRC/N.

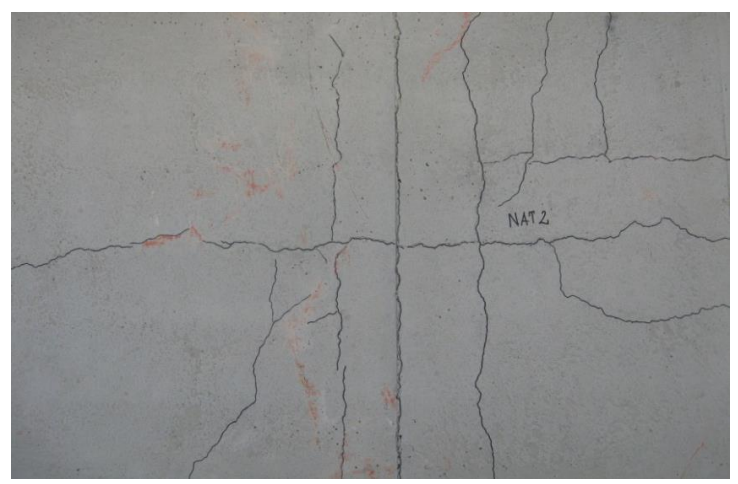

Fig. 7. Experimental cracks for the control slab N.

The observations of the appearing cracks lead to the conclusion that the SFRC surface has a positive effect on limiting their formation in combined slabs, and thus on slowing down damage. The application of a concrete surface with steel fibres scattered in the stressed area has led to an increase in load capacity, the decrease in bending of composite slabs compared with control slabs, and the achievement of a more controlled damage process. 


\subsection{FLEXURAL CAPACITY OF THE COMPOSITE SLAB}

The tested slabs were statically loaded to failure. The failure mechanism of the composite slabs occurred without sliding along the contact surface between the SFRC and ordinary concrete layers.

The mean values of the flexural capacities of the slabs stemming from destructive tests of two series are compared in Table 3.

For the considered slab series, the quantitative effect of strengthening through the SFRC layer on the bending capacity of the slabs was evaluated as the experimental coefficient $m$ [19]:

$$
m=F_{b, S F R C} / F_{b, N}
$$

where:

$F_{b, S F R C}$ - measured mean rupture force of the slab made with the use of SFRC

$F_{b, N}$ - measured mean rupture force of the normal concrete control slab.

Table 3. Rupture force for a series of slabs and coefficient $m$

\begin{tabular}{|c|c|c|}
\hline Series of slabs & Value of rupture force $[\mathrm{kN}]$ & $m$ \\
\hline Composite SFRC/N & 79,$04 ; 78,34 ; 76,99$ & 1.27 \\
\hline Control N & 62,$40 ; 61,32 ; 60,17$ & 1.00 \\
\hline
\end{tabular}

We can observe that the carrying capacity of the composite slab elements of the concrete-concrete type $(\mathrm{SFRC} / \mathrm{N})$ was $27 \%$ higher than that of the homogeneous slabs of made ordinary concrete.

\section{CONCLUSIONS}

- A beneficial effect was observed of the fiber concrete layer regarding deformations, deflections, and load capacity of the composite slabs in comparison with the homogeneous control slabs made of ordinary concrete.

- Experimental testing of the model reinforced concrete slabs showed a decrease in deflection and therefore a beneficial effect of the fiber concrete layer in the combined elements as compared to the homogeneous slabs made of ordinary concrete.

- The carrying capacity of the combined slab elements of the concrete-concrete type (SFRC/N) was higher than that of the homogeneous slabs of ordinary concrete $(\mathrm{N})$.

- It has been found that the use of a fiber concrete layer in the compression zone of a slab element being bent has both a strengthening and a repair role. 


\section{REFERENCES}

1. Park K., Paulino G.H., Roesler J., "Cohesive fracture model for functionally graded fiber reinforced concrete", Cement and Concrete Research, 2010, pp. 956-965.

2. Soranakom CH., Mobasher B., Bansal S., "Effect of material non-linearity on the flexural response of fiber reinforced concrete", Proc. Int. Symp. Brittle Matrix Composites 8, 2006, pp.85-98.

3. Hanzlova H., Vyborny J., Vodicka J., "Comparison of basic mechanical-physical properties and frost resistance of common fine-grained concrete and brickconcrete with fibers and without fibers", Proc. Int. Symp. Brittle Matrix Composites 8, 2006, pp.213-219.

4. Zhang L., Mindess S., "Compressive toughness of fibre reinforced concrete under impact loading”, Proc. Int. Symp. Brittle Matrix Composites 8, 2006, pp.239-249.

5. Brandt A.M., "Tughness of fibre reinforced cement based materials", Archives of Civil Engineering XLII (4), 1996.

6. Vodicka J., Spura D., "Volume Changes of fibre concrete with steel and synthetic fibres", Proc. Int. Symp. Brittle Matrix Composites 8, 2006, pp.285-292.

7. Brandt A.M., Glinicki M.A., Potrzebowski J., "Application of FRC in construction of the underground railway system”, Cement and Concrete Composites, Vol.18, No.5, 1996, 305-312.

8. Brandt A.M., Glinicki M.A., "Investigation of the flexural toughness of fibre reinforced composites (FRC)", Archives of Civil Engineering,Vol. XLV, 3, 1999, pp.399-426.

9. Brandt A.M., "Fibre reinforced cement-based (frc) composites after over 40 years of development in building and civil engineering", Composite Structures 86 (2008) p. 3-9

10. Glinicki M.A., "Testing of macro-fibre reinforced concrete for industrial floors”, Cement, Wapno, Beton, Vol.4, 2008, pp.184-195.

11. Głodkowska W., Kobaka J., "The model of brittle matrix composites for distribution of steel fibers", Journal of Civil Engineering and Management, Vol. 18, Issue 1, 2012, 145-150.

12. S.Furlan Jr, J.Bento de Hanai "Shear behaviour of fibre reinforced concrete beams", Cement and Concrete Composites, Volume 19, Issue 4, 1997, p.359-366.

13. Q. Chunxiang, I. Patnaikumi "Properites of high-strength steel fiber-reinforced concrete beams in bending" Cement and Concrete Composites, Volume 21, Issue 1, 1999, p.73-81.

14. S. Yazici, G. Inan, V. Tabak, "Effect of aspect ratio and volume fraction of steel fiber on the mechanical properties of SFRC" Construction Building Materials 21 (2007), p. 1250-1253.

15. W. Glodkowska, J. Laskowska-Bury "Fiber composite based waste sand as a material for the production of industrial floors", Materialy Budowlane 2015.

16. Fairbairn E.M.R., Toledo Filho R.D., Formagini S., Rosa J.I., Battista R.C., "Experimental analysis and modelling of ultra high performance fiber reinforced concrete plates", International RILEM Workshop on High Performance Fiber Reinforced Cementitious Composites in Structural Applications, 2006,p. 295-302.

17. W. Glodkowska, J.Kobaka, "Modelling of properties and distribution of steel fibres within a fine aggregate concrete" Construction and Building Materials 44 (2013) p.645-653.

18. P.Smarzewski, M.Szwaj, A.Szewczak "Analyses of states of the deformation of slabs of high- and high-fibre reinforced concrete" Building and Architectural 10 (2012) p.37-52.

19. Lapko A.,Sadowska-Buraczewska B., Tomaszewicz A., "Experimental and numerical analysis of flexural composite beams with partial use of High Strength/High Performance Concrete", Journal of Civil Engineering and Management, 2005, Vol. XI, No. 2, p. 115-120.

20. EN 1992-1-1: Eurocode 2: "Design of concrete structures Part 1-1 General rules and rules for building".

21. Model Code 2010.

22. PN-EN 12390:2009 "Testing hardened concrete". 


\section{LIST OF FIGURES AND TABLES:}

Fig. 1. The cubic sample on the testing machine

Rys. 1. Próbka kostkowa w maszynie wytrzymałościowej.

Fig. 2. Experimental test of beam element measuring 100x100x400mm

Rys. 2. Badanie eksperymentalne belki 100x100x400mm

Fig. 3. Reinforcement bars of tested slabs.

Rys. 3. Zbrojenie badanych płyt.

Fig. 4. Loading scheme, cross-sections of tested slabs: SFRC/N - composite slabs, N-control homogeneous slabs made of ordinary concrete.

Rys. 4. Schemat obciążenia, przekrój badanych płyt: SFRC/N - płyty zespolone, N-jednorodne płyty kontrolne wykonane z betonu zwykłego.

Fig 5. Experimental relationships obtained from the experimental analysis of the loading force $F$-deflection $a$.

Rys. 5. Eksperymentalna zależność pomiędzy siłą $F$-ugięciem $a$.

Fig. 6. Experimental cracks of the SFRC/N composite slabs.

Rys. 6. Rysy pomierzone doświadczalnie dla płyt zespolonych SFRC/N.

Fig. 7. Experimental cracks of the control slab N.

Rys. 7. Rysy pomierzone doświadczalnie dla płyt kontrolnych $\mathrm{N}$.

Tab. 1. Data composition and mix characteristics of the concrete used in the tests.

Tab. 1. Dane i właściwości betonów użytych do badań.

Tab. 2. Quantitative effects of the use of the SFRC layer on slab deflection

Tab. 2. Wpływ SFRC na ugięcia płyty.

Tab. 3. Rupture force for series of slabs and coefficient $m$

Tab. 3. Siła niszcząca dla serii płyt i współczynnik $m$ 


\section{WPLYW WARSTWY FIBROBETONU NA UGIECCIA I RYSY W PLYTACH ZESPOLONYCH}

Słowa kluczowe: ugięcia, rysy, fibrobeton z włóknem stalowym, płyty zespolone, nośność, badania doświadczalne

\section{STRESZCZENIE:}

Fibrobeton jest materiałem znanym, o czym świadczyć mogą liczne prace naukowe. W licznych artykułach [1,2] i publikacjach zawarto informacje o fizykomechanicznych właściwościach fibrobetonu [3,4]. Autorka proponuje użycie fibrobetonu z włóknami stalowymi, jako warstwy wzmacniającej lub naprawczej w płytowych elementach zespolonych. W publikacji zamieszczono badania krótkotrwałe płyt zespolonych w zakresie ugięć, rys i nośności w porównaniu z płytami kontrolnymi wykonanymi w całości z betonu zwykłego. Do wykonania elementów wykorzystano odpowiedni fibrobeton, który spełnia narzucone przez autorkę parametry (wytrzymałość betonu na ściskanie ok. 150MPa.). Celem przedstawionych w niniejszej pracy badań eksperymentalnych i analizy wyników jest oszacowanie wpływu warstwy fibrobetonu, zastosowanego w ściskanej górnej strefie elementu na całej długości, na, ugięcia, nośność i rysy zespolonych płyt typu beton-beton w porównaniu z płytami kontrolnymi wykonanymi w całości z betonu zwykłego. W badaniach wykorzystano żelbetowe zespolone płyty o wymiarach 600x1200x80 mm. Płyta zespolona wykonana z dwóch warstw: fibrobetonu na górze i betonu zwykłego na dole. Analiza wyników badań potwierdza znaczącą poprawę właściwości konstrukcji zespolonej w porównaniu z płytami wykonanymi z betonu zwykłego. Na Rys. 1 przedstawiono schemat obciążenia i przekrój płyt zespolonych i kontrolnych.
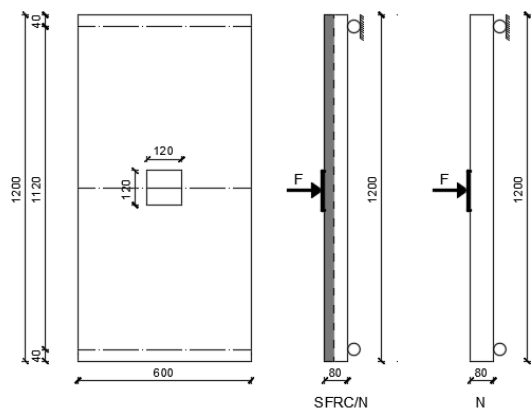

Rys. 1. Schemat obciążenia, przekrój badanych płyt: SFRC/N - płyty zespolone, $\mathrm{N}$ - jednorodne płyty kontrolne wykonane $\mathrm{z}$ betonu zwykłego.

Badania eksperymentalne płyt zespolonych i kontrolnych wykonano na maszynie wytrzymałościowej firmy Controls ze sterowaniem szybkością przyrostu przemieszczenia i rejestracją wartości siły oraz ugięć, będącej na wyposażeniu Katedry Materiałów Technologii i Organizacji Budownictwa na Wydziale Budownictwa i Inżynierii Środowiska Politechniki Białostockiej. Płyty zespolone i kontrolne obciążano miejscowo. Obciążenie przekazywane było w środku elementu, poprzez centrycznie ustawioną płytkę stalową przy stałym wzroście obciążenia co $5 \mathrm{kN}$. Średnie wartości pomierzonych ugięć z 3 elementów badawczych przedstawiono w formie graficznej tj zależności siła-ugięcie jak na Rys. 2. oraz wartości siły niszczącej z trzech pomiarów serii płyt SFRC/N i N pokazano w tablicy 1 . 


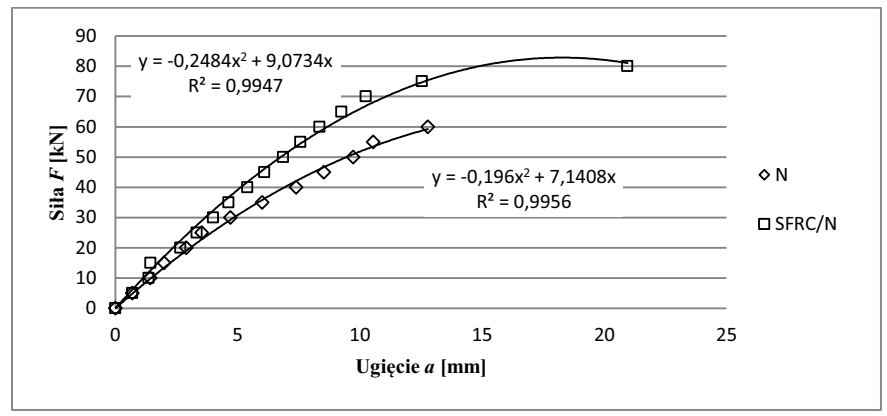

Rys. 2. Eksperymentalna zależność pomiędzy siłą $F$ - ugięciem $a$.

Tablica 1. Siła niszcząca serii płyt SFRC/N i N

\begin{tabular}{|c|c|}
\hline Serie płyt & Wartości sił niszczących $[\mathrm{kN}]$ \\
\hline Zespolona SFRC/N & 79,$04 ; 78,34 ; 76,99$ \\
\hline Kontrolna N & 62,$40 ; 61,32 ; 60,17$ \\
\hline
\end{tabular}

\section{WNIOSKI}

- Zaobserwowano korzystny wpływ warstwy fibrobetonu na ugięcia i nośność płyt zespolonych w porównaniu z płytami kontrolnymi wykonanymi całkowicie z betonu zwykłego.

- Użycie warstwy fibrobetonu w strefie ściskanej elementu płytowego spełnia rolę wzmacniającą i naprawczą

\section{LITERATURA}

1. Soranakom CH., Mobasher B., Bansal S., Effect of material non-linearity on the flexural response of fiber reinforced concrete, Proc. Int. Symp. Brittle Matrix Composites 8, 2006, pp.85-98.

2. Hanzlova H., Vyborny J., Vodicka J., Comparison of basic mechanical-physical properties and frost resistance of common fine-grained concrete and brickconcrete with fibers and without fibers, Proc. Int. Symp. Brittle Matrix Composites 8, 2006, pp.213-219.

3. Brandt A.M. ., Tughness of fibre reinforced cement based materials, Archives of Civil Engineering XLII (4), 1996.

4. Głodkowska W., Kobaka J., The model of brittle matrix composites for distribution of steel fibers, Journal of Civil Engineering and Management, Vol. 18, Issue 1, 2012, 145-150. 